\title{
The Maastrichtian Stage in NW Europe, and its brachiopod zonation
}

FINN SURLYK

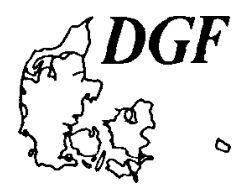

Surlyk, F.: The Maastrichtian Stage in NW Europe, and its brachiopod zonation. Bull. geol. Soc. Denmark, vol. 33, pp. 217-223, Copenhagen, September, 11th, 1984. https://doi.org/10.37570/bgsd-1984-33-20

The uppermost Campanian-Maastrichtian of NW Europe is divided into twelve brachiopod zones. Each zone is defined by its lower boundary in a stratotype by the appearance or disappearance of a species. The upper boundary is then formed by the lower boundary of the next succeeding zone. The zones are given binomial names using the species names of the taxa defining the lower and upper boundary respectively. The zonation is mainly based on localities in Denmark and most of the zones can be traced to Sweden, Poland, DDR, NW-Germany and eastern England. The section at Kronsmoor, NW Germany is proposed as stratotype for the lower boundary of the Maastrichtian Stage. Stevns Klint is by definition stratotype for the upper boundary and thus for the Cretaceous-Tertiary boundary. It may be substituted by Nye Kløv, Denmark if it can be demonstrated that it contains a hiatus at the boundary. It is formally proposed to place the boundary at the base of the Fish Clay since all available evidence points towards a global isochronous nature of the boundary clay bed.

Finn Surlyk, Grønlands Geologiske Undersøgelse, Øster Voldgade 10, 1350 København K, Danmark, February 8th, 1984.

\section{Introduction}

The Maastrichtian Stage was proposed by Dumont (1850) on the basis of localities and faunas from eastern Holland. The stage was very loosely defined and has been subject of considerable discussion as regards delimitation, rank, correlatives and even spelling (e.g. Berggren, 1964; van Gorsel, 1973; van der Heide, 1954; Jeletzky, 1951a, b; El-Naggar, 1966; Romein, 1962, 1963; Schmid, 1955, 1956, 1959, 1967; Seitz, 1952; Sissingh, 1978; Surlyk, 1982; Thiadens, 1970; Voigt, 1956). There now seems to be general agreement on the following points:

1) The Maastrichtian has the rank of a stage.

2) The correct spelling is Maastrichtian (not Maestrichtian).

3) The type section is in the E.N.C.I. quarry in Limbourg, Eastern Holland.

4) The type section includes only a part of the Upper Maastrichtian Substage as generally defined.

5) The stage corresponds roughly to the Hoploscaphites constrictus Range Zone.

6) The base of the stage is generally (in NW Europe) defined by the first occurrence of Belemnella lanceolata.
The section at Kronsmoor was proposed as a stratotype of the lower boundary by Surlyk $(1975,1982)$ and Schulz (1978). It was discussed during the present symposium organised by the Subcommission of Cretaceous Stratigraphy (see Birkelund et al., this volume).

It is here formally proposed that the upper boundary of the stage is defined by the base of the lowest Danian bed, the Fish Clay in Stevns Klint, Denmark and not by a biostratigraphic marker. All available evidence points towards a global isochronous nature of the boundary clay, which makes it ideal in the definition of a major chronostratigraphic boundary. The Stevns Klint section may be substituted by the section at Nye Kløv, NW Denmark, if it can be demonstrated that it contains a hiatus at the boundary. Nye $\mathrm{K} \emptyset \mathrm{v}$ is (one of) the most complete Cretaceous Tertiary boundary sequences known in the world.

The biostratigraphic zonation of the Maastrichtian of NW Europe including Great Britain has mainly been based on foraminifera, coccoliths, dinoflagellates, belemnites and brachiopods. The by far most detailed and applicable zonation in this area has been worked out on the brachiopods (Steinich, 1965; Surlyk, 1969, 1970, 1972, 1975, 1982; Bitner \& Pisera, 1979). 


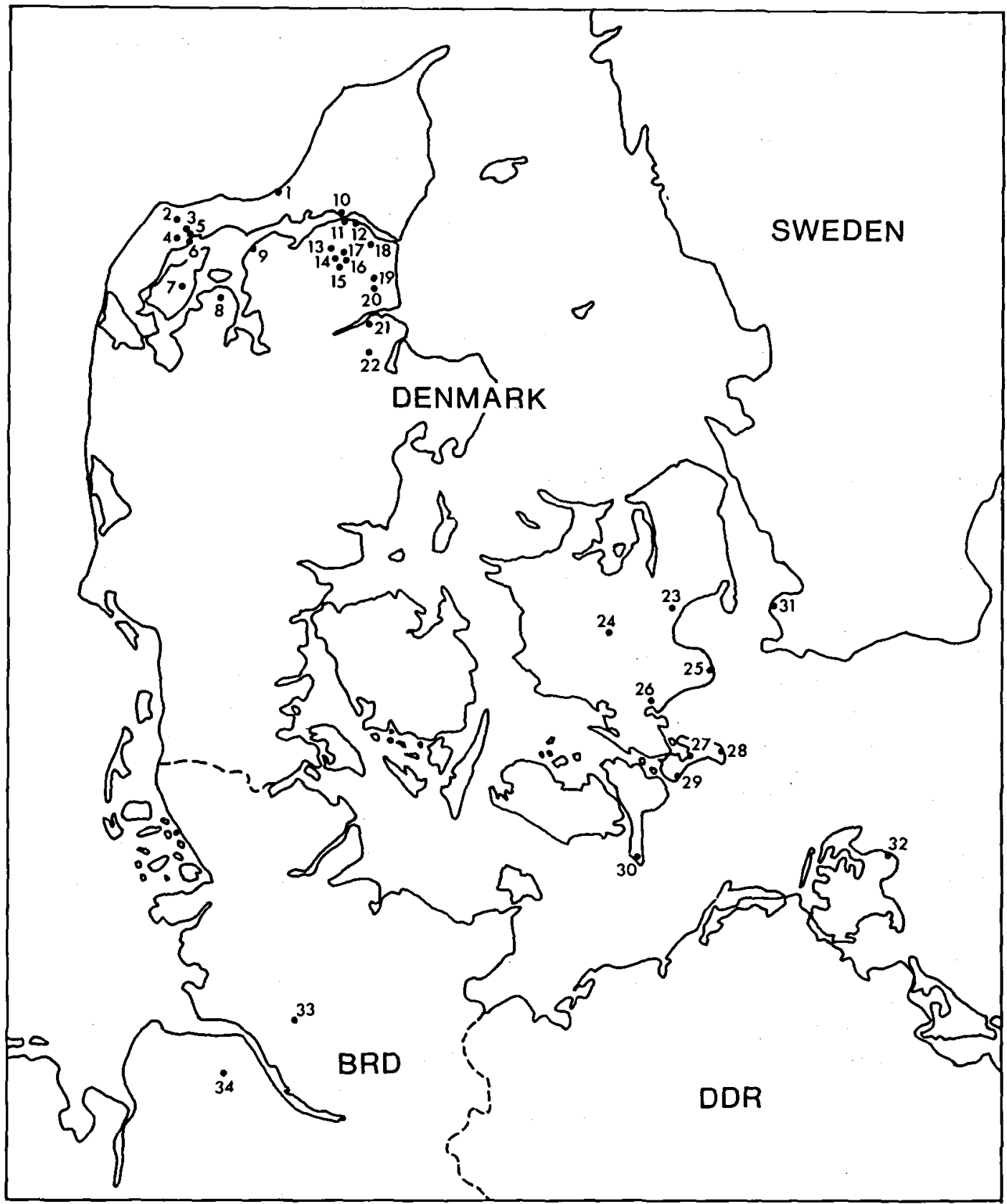

Fig. 1. Map showing the position of the examined late Campanian and Maastrichtian localities. 1. Svinkløv, 2. Bjerre, 3. Kjølbygård, 4. Hillerslev, 5. Nye Kløv, 6. Hov, 7. Eerslev, 8. Batum, 9. Aggersund, 10. Lindholm, 11. "Danmark", 12. Rørdal, 13. Nørre Flødal, 14. "Linds Kalkværk", 15. Ellidshøj, 16. Mjels, 17. Ferslev, 18. Gudumholm, 19. Sønder Kongerslev, 20. Smidie, 21. "Dania", 22. Spentrup, 23. Karlstrup, 24. Allindelille, 25. Stevns Klint, 26. Kongsted, 27. Lille Bissinge, 28. Møns Klint (Jættebrink, Hundefangsklint, Hvidskud, Lille Stejlebjerg, Store Stejlebjerg, Gråryg, Nellerendenakke, Sommerspir, Sandpynt, Maglevandspynt, Forchhammers Pynt, Vitmunds Nakke, Nylands Nakke, Sattepileklint, Store Taler, Lille Taler, Slotsgavlene), 29. Hvide Klint, 30. Gedser Fyr and Gedser Odde, 31. Limhamn, 32. Rügen, 33. Kronsmoor, 34. Hemmoor. 
The highest part of the Maastrichtian of Denmark has, however, been subdivided into even greater detail by means of dinoflagellates (Hansen, 1977, 1979). Foraminifera and coccoliths have been of limited use for detailed subdivision and have their main importance in long distance correlation.

Denmark occupies a key position in the biostratigraphic study of the Maastrichtian of NW Europe, because the stage reaches very great thicknesses, is exposed in a large number of sections, is developed in a uniform highly fossiliferous chalk lithology, and because of the presence of the upper boundary statotype.

The Maastrichtian of Denmark was subdivided into 10 zones on the basis of a very large material of mainly micromorphic brachiopods obtained by washing of bulk samples from all known Danish localities by Surlyk $(1969,1970)$. This zonation could be correlated with an earlier zonation of the Rügen chalk (Steinich, 1965) and was extended to NW Germany (Surlyk, 1970, 1975, 1982), Sweden (Surlyk, 1969), eastern England (Surlyk \& Johansen, in prep.), and Poland (Bitner \& Pisera, 1979). The Danish zonation was described in detail in an unpublished thesis (Surlyk, 1969) and only a summary of the zonation has been published (Surlyk, 1970).

In the present paper a coherent brachiopod zonation for the Maastrichtian chalk of Sweden, Denmark, NW Germany, East Germany and eastern England is presented for the first time. Sections from Poland, Holland and Belgium are incorporated in the zonation as far as their brachiopod faunas are known. The zonal nomenclature follows the system porposed by Murphy (1977). This system was introduced for the Upper Cretaceous chalk of NW Europe in a paper on the Campanian-Maastrichtian boundary sequence at Kronsmoor (Surlyk, 1982).

Each zone is defined by its boundaries, each boundary is defined in a stratotype by a palaeontological event, and only one taxon is used in the definition of a zone boundary. The upper boundary of each zone is automatically defined by the lower boundary of the overlying unit. A zone is given a binomial name using the species names of the taxa defining the lower and upper boundary respectively. Species which are particularly common, or which seem to appear or disappear in a consistent position with respect to the boundaries are indicated as characteristic species.

The zones until now recognized in NW Europe are described below in a standardized way. They are from oldest to youngest:

tenuicostatus - longicollis Zone

Age: Late-latest Campanian.

Base: Start of $R$. tenuicostata. No stratotype.

Characteristic species: $R$. tenuicostata, $R$. spinosa s.l. (see Surlyk, 1982).

longicollis - jasmundi. Zone

Age: Latest Campanian - Campanian/Maastrichtian boundary.

Base: Start of $T$. longicollis.

Stratotype: Kronsmoor sample 8 (see Surlyk, 1982).

Characteristic species: T. longicollis, R. acutirostris.

jasmundi - acutirostris Zone

Age: Earliest Maastrichtian. Corresponds to zone 1 or to an interval between zones 1 and 2 of Surlyk (1970).

Base: Start of G. jasmundi.

Stratotype: Kronsmoor sample 10 (see Surlyk, 1982). .

Characteristic species: G. jasmundi, T. gracilis.

acutirostris - spinosa Zone

Age: Early Early Maastrichtian. Corresponds roughly to Zone 2 of Surlyk (1970).

Base: Start of $R$. acutirostris.

Stratotype: Kronsmoor sample 13 (see Surlyk, 1982).

Characteristic species: $R$. acutirostris, G. gisii, $G$. jasmundi, T. gracilis, $M$. chitoniformis, $D$. mielnicensis.

spinosa - subtilis Zone

Age: Early Maastrichtian. Corresponds to zone 3 of Surlyk (1970) and almost exactly to the obtusa Zone of Schulz (1979).

Base: Last occurrence of $R$. spinosa.

Stratotype: Kronsmoor sample 18 (see Surlyk, 1982).

Characteristic species: $G$. jasmundi, $R$. tenuicostata, T. gracilis. 


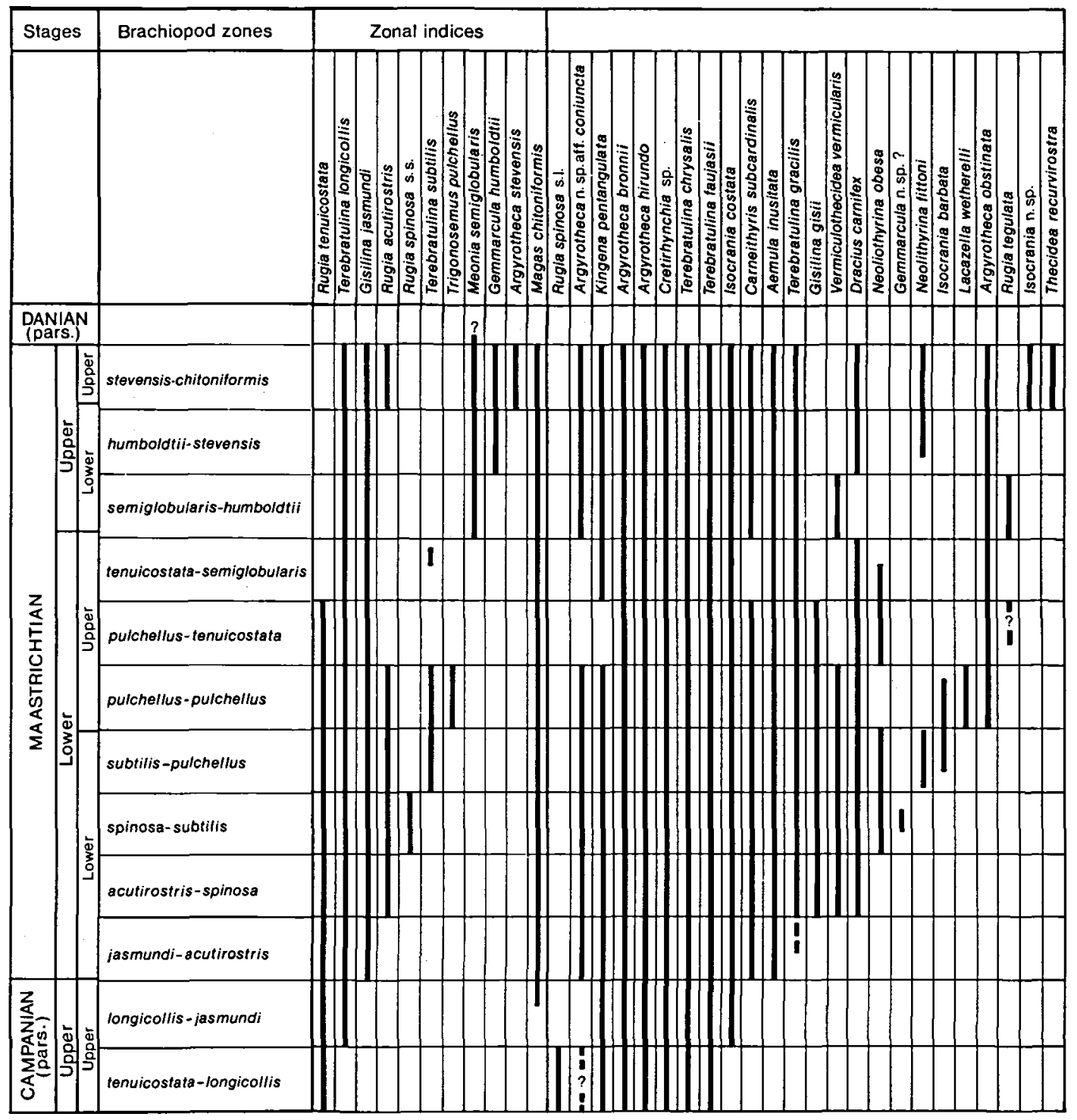

Fig. 2. Stratigraphic range chart for the late Campanian-Maastrichtian brachiopods of NW Europe. Only information obtained from well horisonted bulk samples is included. Some rare or little known species are excluded from the diagram as are the species Dalligas nobilis, D. mielnicensis, and Scumulus inopinatus which at present are under revision.

subtilis - pulchellus Zone

Age: Early Early Maastrichtian. Corresponds to zone 4 of Surlyk (1970) and includes zone 1 of Steinich (1965).

Base: Start of T. subtilis.

Stratotype: Hvidskud, Møns Klint, sample 9 (Surlyk, 1972, fig. 14).

Characteristic species: T. subtilis, G. gisii, G. jasmundi, R. tenuicostata, T. faujasii. pulchellus - pulchellus Zone

Age: Late Early Maastrichtian. Corresponds to zone 5 of Surlyk (1970) and zone 2 of Steinich (1965).

Base: Start of T. pulchellus.

Stratotype: Hvidskud, Møns Klint, sample 5 (Surlyk, 1972, fig. 14).

Characteristic species: T. pulchellus, $R$. tenuicostata, G. gisii, G. jasmundi. 


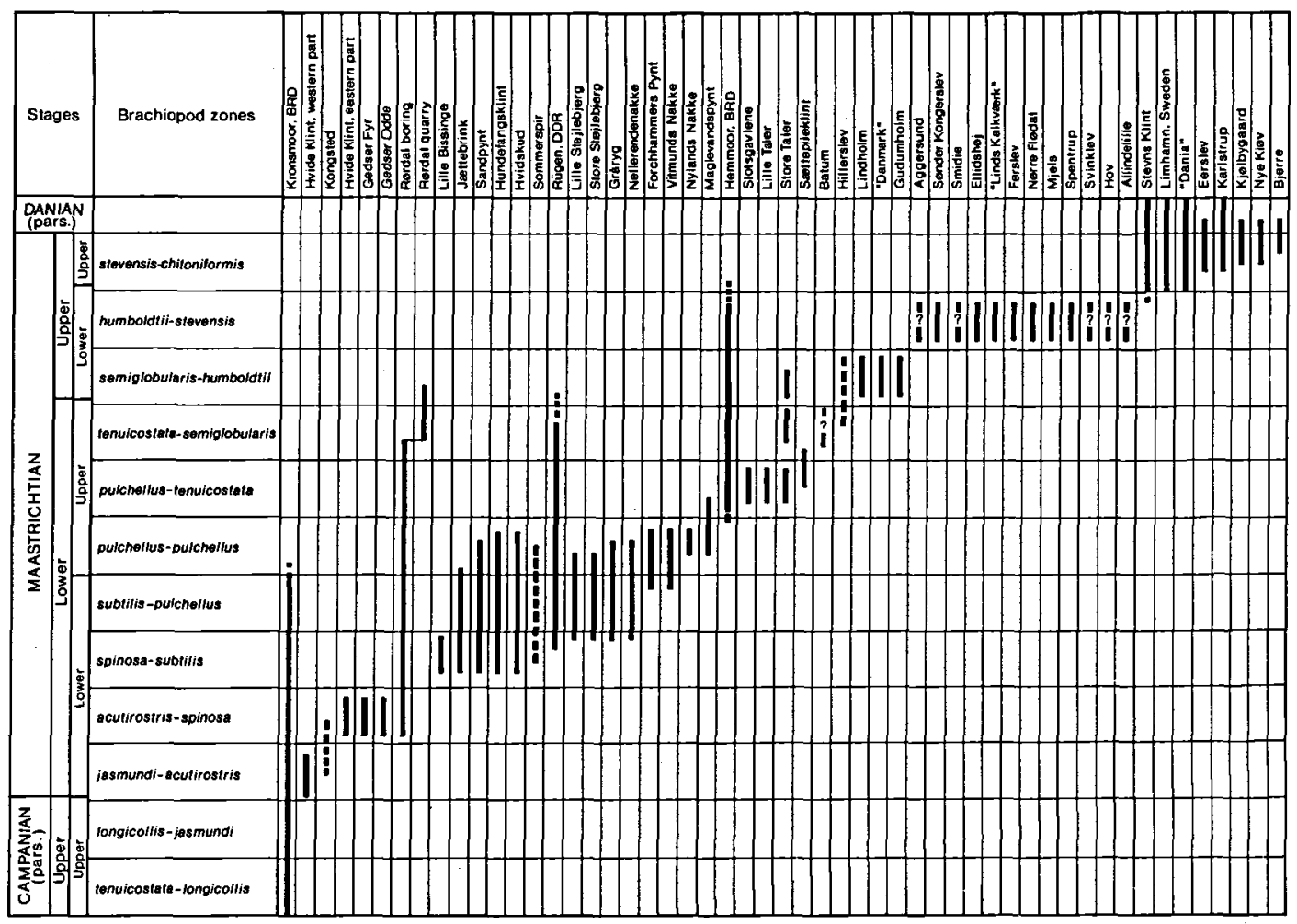

Fig. 3. Scheme showing the stratigraphic distribution of the main Danish Maastrichtian localities. The NW German sections at Kronsmoor (Surlyk 1982) and Hemmoor (Surlyk 1970, 1975) and the section at Rügen, DDR (Data from Stenich, 1965) are included.

pulchellus - tenuicostata Zone

Age: Late Early Maastrichtian. Corresponds to zone 6 of Surlyk (1970).

Base: Last occurrence of $T$. pulchellus.

Stratotype: Chalk complex 8 , sample 18 , Rügen (Steinich, 1965, fig. 296).

Characteristic species: G. gisii, G. jasmundi, R. tenuicostata.

tenuicostata - semiglobularis Zone

Age: Latest Early Maastrichtian. Corresponds to zone 7 of Surlyk (1970).

Base: Last occurrence of $R$. tenuicostata.

Stratotype: Hemmoor sample 82 (see section in Schmid, 1982).

Characteristic species: The fauna is of low diversity and the zone is essentially characterized by the disappearance of several important Lower Maastrichtian species at the lower boundary, and the appearance of the main Upper Maastrichtian index $M$. semiglobularis at the upper boundary. semiglobularis - humboldtii Zone

Age: Early Late Maastrichtian. Corresponds to zone 8 of Surlyk (1970).

Base: Start of Meonia semiglobularis.

Stratotype: Hemmoor sample 95 (see section in Schmid, 1982).

Characteristic species: $M$. semiglobularis, Rugia tegulata, $T$. gracilis.

\section{humboldtii - stevensis Zone}

Age: Mid Late Maastrichtian. Corresponds to zone 9 of Surlyk (1970).

Base: Start of Ruegenella humboldtii.

Stratotype not designated as $R$. humboldtii is relatively rare. Usually some specimens are found in each locality exposing strata of this age if just a few samples are examined. Steinich (1965) indicated $R$. humboldtii occurring at the very top of the Rügen section, i.e. at the top of the Lower Maastrichtian, but has elsewhere mentioned the possibility that the specimens were out of place (Steinich, 1972). If, however, the start of $R$. hum- 
boldtii is strongly diachronous starting much earlier in East Germany than in Denmark it will eventually have to be dropped as defining a zone boundary.

Characteristic species: $R$. humboldtii, Meonia semiglobularis, Magas chitoniformis, Terebratulina gracilis.

stevensis - chitoniformis Zone

Age: Latest Maastrichtian to the MaastrichtianDanian boundary. Corresponds to zone 10 of Surlyk (1970).

Base: Start of $A$. stevensis.

Stratotype: Stevns Klint, lowest part of the section. The Maastrichtian brachiopod fauna experienced a sudden mass-extinction at the Cretaceous-Tertiary boundary (Surlyk \& Johansen, 1982, 1984). Any of the disappearing Maastrichtian brachiopod species can be selected to define the lower boundary of the next succeeding zone of earliest Danian age. As a brachiopod zonation has not yet been worked out for the Danian Stage the top of the stevensis-chitoniformis Zone is defined by the disappearance of one of the most characteristic Maastrichtian species, Magas chitoniformis.

\section{Mass-extinction of the Maastrichtian brachiopod fauna.}

The Maastrichtian brachiopod fauna of Denmark consists of about fifty species. Johansen (1982) and Surlyk \& Johansen (1984) demonstrated the extinction pattern for one locality, Nye Kløv. The general validity of the data from Nye Kløv was checked with data from several other boundary localities (F. Surlyk, 1969 and unpublished data). When all boundary localities are included the number of species becoming extinct becomes even more impressive. Fig. 2 shows a schematic range chart for all the Maastrichtian brachiopod species of NW Europe. The chart only shows occurrence on zone level as the data are mainly obtained from a very large number of relatively short sections rather from a few very long sections. Of the 50 recognised Maastrichtian species only 6 are known with certainty from the Danian Stage. A few additional species may occur in the basal Danian strata but this still has to be confirmed. Some of the extinct species disappear at different levels of the Maastrichtian, but 38 species still occur in the highest Maastrichtian zone, the stevensis-chitoniformis Zone. Most or all of these species become extinct right at the boundary.

\section{Age of the Maastrichtian localities in NW Europe}

The brachiopod zonation of the NW European chalk is based on a large number of samples from several selected long sections. These sections are Hvidskud on Møns Klint, Rørdal quarry and boring, Stevns Klint, "Dania" quarry, Kronsmoor and Hemmoor in NW Germany, Rügen in DDR (Stenich, 1965). In addition virtually all other localities in the region has been sampled to test and refine the basic zonation. Many of these localities were dated for the first time. Others had previously only been very crudely dated to substage level. Figure 3 shows the stratigraphic range of the localities. The work on the English sections is still in progress and is not presented here.

Acknowledgements. This paper gives a short synthesis of an extensive study of the stratigraphy, taxonomy and palaeoecology of the brachiopods of NW Europe supported by the Carlsberg Foundation. N. Turner and B. Sikker Hansen are thanked for their assistance in the preparation of the manuscript.

\section{Dansk sammendrag}

Det øverste campanien-maastrichtien i nordvest Europa inddeles $\mathrm{i}$ dette arbejde $\mathrm{i}$ tolv brachiopod zoner. Hver zone er defineret i en stratotype ved første eller sidste optraden af en art. Zonens øvre granse er automatisk defineret af den følgende zones nedre grænse. Zonenavnene er binomiale, dannet af artsnavnene på de arter, der definerer henholdsvis nedre og øvre grænse. Eksempelvis er subtilis - pulchellus zonens nedre grænse defineret ved den første optræden af Terebratulina subtilis og dens øvre grænse ved den første optræden af Trigonosemus pulchellus. Zoneringen, der især bygger på lokaliteter i Danmark, kan følges til Sverige, Polen, Vesttyskland, Østtyskland og England. Kronsmoor profilet i nordvest Tyskland foreslås som stratotype for maastrichtien etagens nedre grænse. Stevns Klint er per definition stratotype for etagens øvre grænse og dermed for kridt - tertiær grænsen. Det foreslàs her, at Stevns Klint kan erstattes af Nye Kløv i Hanherred, hvis det kan påvises, at Stevns Klint profilet indeholder en hiatus ved grænsen. Det foreslås, at kridt - tertiær grænsen placeres ved basis af fiskeleret, idet alle oplysninger peger på, at grænselerlaget repræsenterer en isokron horisont over det meste af jorden. 


\section{References}

Berggren, W. A. 1964: The Maestrichtian, Danian and Montian Stages and the Cretaceous-Tertiary boundary. Stockh. Contrib. Geol. 11, 103-176.

Bitner, M. A. \& Pisera, A. 1979: Brachiopods from the Upper Cretaceous chalk of Mielnik (Eastern Poland). Acta geol. Pol. 29, 67-88.

Dumont, A. 1850: Rapport sur la carte geologique de royaume. Acad. Roy. Sci. Lettres, Beaux-Arts, Belgique Bull. 16, 351-373.

El-Naggar, Z. R. 1966: Stratigraphy and planktonic foraminifera of the Upper Cretaceous-Lower Tertiary succession in the Esna-Idfu region, Nile Valley, Egypt, UAR. Bull. Br. Mus. Nat. Hist. (Geology, Supplement) 2, 1-279.

Gorsel, J. T. van 1973: The type Campanian and the Campanian-Maastrichtian boundary in Europe. Geol. Mijnb. 52, 141-146.

Hansen, J. M. 1977: Dinoflagellate stratigraphy and echinoid distribution in Upper Maastrichtian and Danian deposits from Denmark. - Bull. geol. Soc. Denmark 26, 1-26.

Hansen, J. M. 1979: A new dinoflagellate zone at the Maastrichtian/Danian boundary in Denmark. Danmarks geol. Unders., Arbog 1979, 131-140.

Heide, S. van der 1954: The original meaning of the term Maastrichtian (Dumont 1849). Geol. Mijnb. 16, 509-511.

Jeletzky, J. A. 1951a: Die Stratigraphie und Belemnitenfauna des Obercampan und Maastricht Westfalens, Nordwestdeutschlands und Dänemarks sowie einige allgemeine Gliederungs-Probleme der jüngeren borealen Oberkreide Eurasiens. Beih. geol. Jb. 1,1-142.

Jeletzky, J. A. 1951b: The Place of the Trimingham and Norwich Chalk in the Campanian-Maestrichtian Succession. Geol. Mag., 88, 197-208.

Johansen, M. B. 1982: Den faunistiske udskiftning of brachiopoderne pd Maastrichtien/Danien graensen, lokalitet Nye Kløv, Nordjylland (systematik, palaoøkologiske og evolutionare aspekter). Unpublished Thesis University of Copenhagen, $270 \mathrm{pp}$.

Murphy, M. A. 1977: On time-stratigraphic units. J. Paleont. 51, 213-219.

Peake, N. B. \& Hancock, J. M. 1970: The Upper Cretaceous of Norfolk. In Larwood, G. P. \& Funnell, B. M. (eds). The Geology of Norfolk, 293-339 J.

Romein, B. J. 1962: On the type locality of the Maastrichtian (Dumont 1849), the upper boundary of that stage and on the transgression of a Maastrichtian s.l. in Southern Limbourg. Medd. Geol. Sticht. N. S. 15, 77-84.

Romein, B. J. 1963: Present knowledge of the stratigraphy of the Upper Cretaceous (Campanian-Maastrichtian and Lower Tertiary (Danian-Montain) calcareous sediments in southern Limbourg. Verh. kon. ned. Geol. Mijnb. Genoot., Geol. Serie 21, 93-104.

Schmid, F. 1955: Biostratigraphie der Grenzschichten Mastricht/Campan in Lüneburg und in der Bohrung Brunhilde. 1. Teil: Megafauna und Schichtfolge. Geol. Jb. $70,339-356$.

Schmid, F. 1956: Jetziger Stand der Oberkreide-Biostratigraphie in Nordwestdeutschland: Cephalopoden. Paläont. Z. $30,7-10$.
Schmid, F. 1959: Biostratigraphie du Campanien-Maastrichtien du NE de la Belgique sur la base des Belemnites. Ann. Soc. Geol. Belg. 82, 235-256.

Schmid, F, 1967: Die Oberkreide-Stufen Campan und Maastricht in Limburg (Südniederlande, Nordostbelgien), bei Aachen und in Nordwestdeutschland. Ber. dt. Ges. Geol. Wiss. A. Geol. Paläont. 12, 471-478. Berlin.

Schmid, F. 1982: Das erweiterte Unter-/Ober-MaastrichtGrenzprofil von Hemmoor, Niederelbe (NW-Deutschland). Geol. $J b$. A 61, 7-12.

Schulz, M.-G. 1978: Zur Litho- und Biostratigraphie des Obercampan-Untermaastricht von Lägerdorf und Kronsmoor (SW-Holstein). Newsl. Stratigr. 7, 73-89.

Schulz, M.-G. 1979: Morphometrisch-variationsstatistische Untersuchungen zur Phylogenie der Belemniten-Gattung Belemnella im Untermaastricht NW Europas. Geol. Jb. A 47, 3-157.

Seitz, O. 1952: Die Oberkreide-Gliederung in Deutschland nach ihrer Anpassung an das internationale Schema. Zeitschr. Geol. Ges. 104, 148-151.

Sissingh, W. 1978: Microfossil biostratigraphy and stage-stratotypes of the Cretaceous. Geol. Mijnb. 57, 433-440.

Steinich, G. 1965: Die artikulaten Brachiopoden der rügener Schreibkreide (Unter-Maastricht), Palänt. Abh. A, 2, 1-220.

Steinich, G. 1972: Endogene Tektonik in den UnterMaastricht-Vorkommen auf Jasmund (Rügen). Geologie, Jahrg. 20, Beih. 71/72, 1-205.

Surlyk, F. 1969: En unders $\varnothing$ gelse over de articulate brachiopoder $i$ det danske skrivekridt ( $\phi$. campanien og maastrichtien) med en oversigt over skrivekridtets sedimentologi og skrivekridthavets flora og fauna. Diss. Univ. Copenhagen; 319 S., Copenhagen. - (Unpublished).

Surlyk, F. 1970: Die Stratigraphie des Maastricht von Dänemark und Norddeutschland aufgrund von Brachiopoden. Newsl. Stratigr. 1, 7-16.

Surlyk, F. 1972: Morphological adaptations and population structures of the Danish chalk brachiopods (Maastrichtian, Upper Cretaceous). Biol. Skr. Dan. Vid. Selsk. 19,1-57.

Surlyk, F. 1975: Die Brachiopoden der Hemmoorer Schreibkreide. - Paläont. Ges. 45. Jahresversammlung in Hannover, 1 p.

Surlyk, F. 1982: Brachiopods from the Campanian-Maastrichtian boundary sequence, Kronsmoor (NW Germany). Geol. Jb. A 61, 259-277.

Surlyk, F. \& Johansen, M. B. 1982: Introduction: Mass extinction and sedimentological implications. The Cretaceous. Tertiary boundary events JAS 3rd Eur. Mtg., Copenhagen, 1982, Abstr., 112-113.

Surlyk, F. \& Johansen, M. B. 1984: End-Cretaceous brachiopod extinctions in the chalk of Denmark. Science, 223, $1174-1177$

Thiadens, A. A. 1970: Subcommission on the Upper Cretaceous stratigraphy. Rep. 23rd int. geol. Congr., Prague 1968, General proc.: 220-222.

Voigt, E. 1956: Zur Frage der Abgrenzung der MaastrichtStufe. Paläont Z. 30, 11-17.

Wood, C. J. 1967: Some new observations on the Maestrichtian stage in the British Isles. Bull. geol. Surv. G. B. 27, 271288. 